\title{
Statyba
}

\section{ADAPTATION OF STANDARD INFORMATION ON CRANES TO THE REQUIREMENTS OF AN EXPERT SYSTEM}

\section{Hajdasz MSc (civil engineering) \& A. Marlewski PhD (mathematics)}

To cite this article: M. Hajdasz MSc (civil engineering) \& A. Marlewski PhD (mathematics) (1998) ADAPTATION OF STANDARD INFORMATION ON CRANES TO THE REQUIREMENTS OF AN EXPERT SYSTEM, Statyba, 4:4, 297-303, DOI: 10.1080/13921525.1998.10531421

To link to this article: https://doi.org/10.1080/13921525.1998.10531421

Published online: 26 Jul 2012.

Submit your article to this journal $₫$

Џ Article views: 88

4 Citing articles: 2 View citing articles 


\title{
ADAPTATION OF STANDARD INFORMATION ON CRANES TO THE REQUIREMENTS OF AN EXPERT SYSTEM
}

\author{
M. Hajdasz, A. Marlewski
}

\section{Introduction}

The acquisition and the representation of the natural knowledge (ie furnished by catalogues, experience on technological and design processes etc) are considered [1] to be one of the most difficult and important tasks in building an expert system. All the time this research work is discussed and there are no ready solutions in this area [2]. In particular, this concerns the selection of cranes working all over the world within different building technologies [3]. In this article we deal with this subject which is integrally involved in the decision process concerning the design of technology and organisation of monolithic construction. Treating this question (exampli-fied in the realisation of grain silo) we take into account the specificity of computer technique and we put stress on the way by which the natural knowledge can be inserted to a friendly-user system for computer-aided design of monolithic construction (such as this reported in [4]).

\section{Acquisition of the data}

In the documentation, some technological features of cranes (such as the changes of lifting capacity in the operating range) are supplied in the form of tables or graphs. Let us say here this truism that graphs are more readable, this is enough to glance at a graph to estimate if, for example (Fig 1), the crane can transport a load of $40 \mathrm{kN}$ at the distance of 20 meters. Unfortunately, charts supplied within the documentation can not be simply included in the knowledge system stored in a computer (and the scanning has nothing to do with it if we do not want to restrict ourselves to show it only). Tables demand much more user's work (he has to interpolate values), so they are not bidden welcome. But, on the other hand, they are much more adaptable to the requirements of the digital technique [5]. Nevertheless, a good computer program tries to avoid tables, because in general they occupy a lot of memory and the use of them needs some additional operations (especially the interpolating process has to be performed). A preferable way is to store a relatively simple mathematical expression. In general, it is not easy to obtain an appropriate algebraic function ([3], [6]), but the effort paid in it is well recompensed by a quick evaluation and plotting a graph.

Let us consider the typical situation when we deal with cranes. In order to concretise our discussion we will talk about the cranes Waryński-Wolf 5520 SL-6/10 (on the licence from German enterprise MAN GHH Logistics) and ŻB-75/100 (produced by ZREMB FAMABUD Szczecin). The data on these machines are supplied in the catalogues. Data furnished for one crane are not specified for another or are presented in different form. This illustrates that there are problems in getting a complete and compatible information.

\section{Natural presentation and computer representation of the lifting capacity dependence on the operation range}

For different types of cranes (as well as for various combinations of segments which form the tower and the jib) their load capacity changes (as the range changes) in different ways (for example, Fig 1 and 2 where the non-linear and linear behaviour take place). In non-linear case almost everywhere (exceptions are at most at a single point) this dependence is smooth. It means that a curve illustrating this behaviour is continuous and has no points at which dramatically changes its orientation.

The lifting capacity of the crane Waryński-Wolf (its arm can move horizontally only and it can be arranged for the work with a single or double-pulley block) is described in the tables valid if we operate up to $42 \mathrm{~m}$ in altitude. If we move horizontally a load over the distance up to approximately 15 meters, the capacity remains constant (equal to $100 \mathrm{kN}$ ). For further transportation, ie in the range from $15 \mathrm{~m}$ up to 


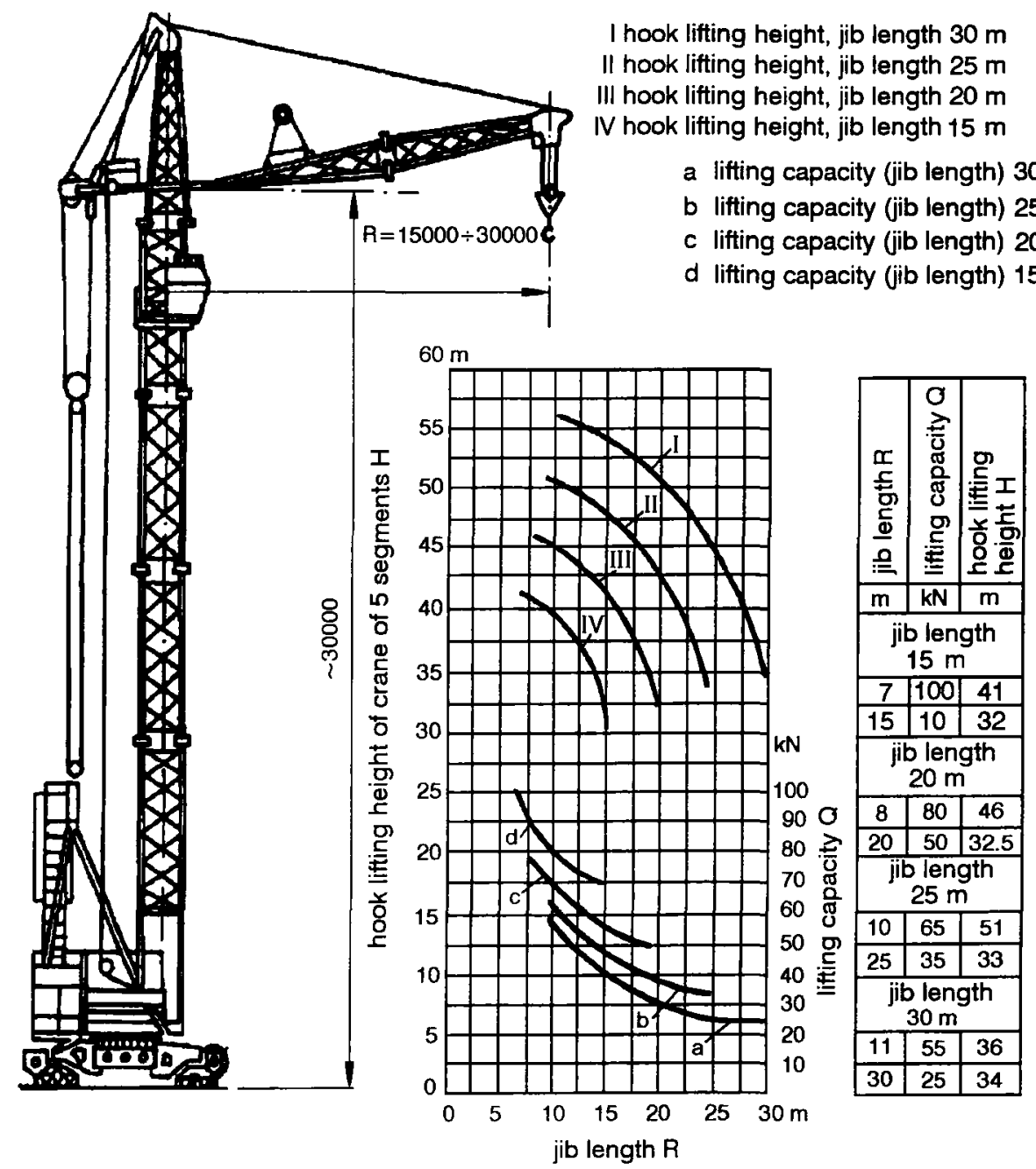

Fig 1. Information on the crane $\dot{Z} B-75 / 100$ as presented in the catalogue [8]

the length of the jib, the capacity changes monotonically. One can describe mathematically these changes and it is easily verified that they are hyperbolic. If the cranes operate in the levels higher than 42 meters, we have to correct the values listed in the tables: we must decrease them always by 4.8 kilograms as we move 1 meter upwards.

The data on the crane ŻB-75/100 (Fig 1) say that the load capacity depends on the length of the jib in a similar way as in case of the crane Waryński-Wolf. In particular, it says that the changes are hyperbolic. Unfortunately, the trials to describe them in this way failed. The cosine approximation fails, too. Detailed investigations show that within the working scope the behaviour is parabolic, ie it can be described (at a very high accuracy) by the polynomial equation of 2 nd degree (these equations are listed in the body of the function loadCapEq below). It does not shock if we pay no significance to the area being out of the working scope (in the considered case it reaches the distance of $30,25,20$ and 15 meters from the axis of the tower, depending on the configuration of the crane).

Let us mention that it is not enough to find the equation for any behaviour and next to modify it to obtain the relation valid for other height of tower or the length of the jib. The dependencies do not observe any simple rule (as the translation or the scaling) for reproducing one from another. 


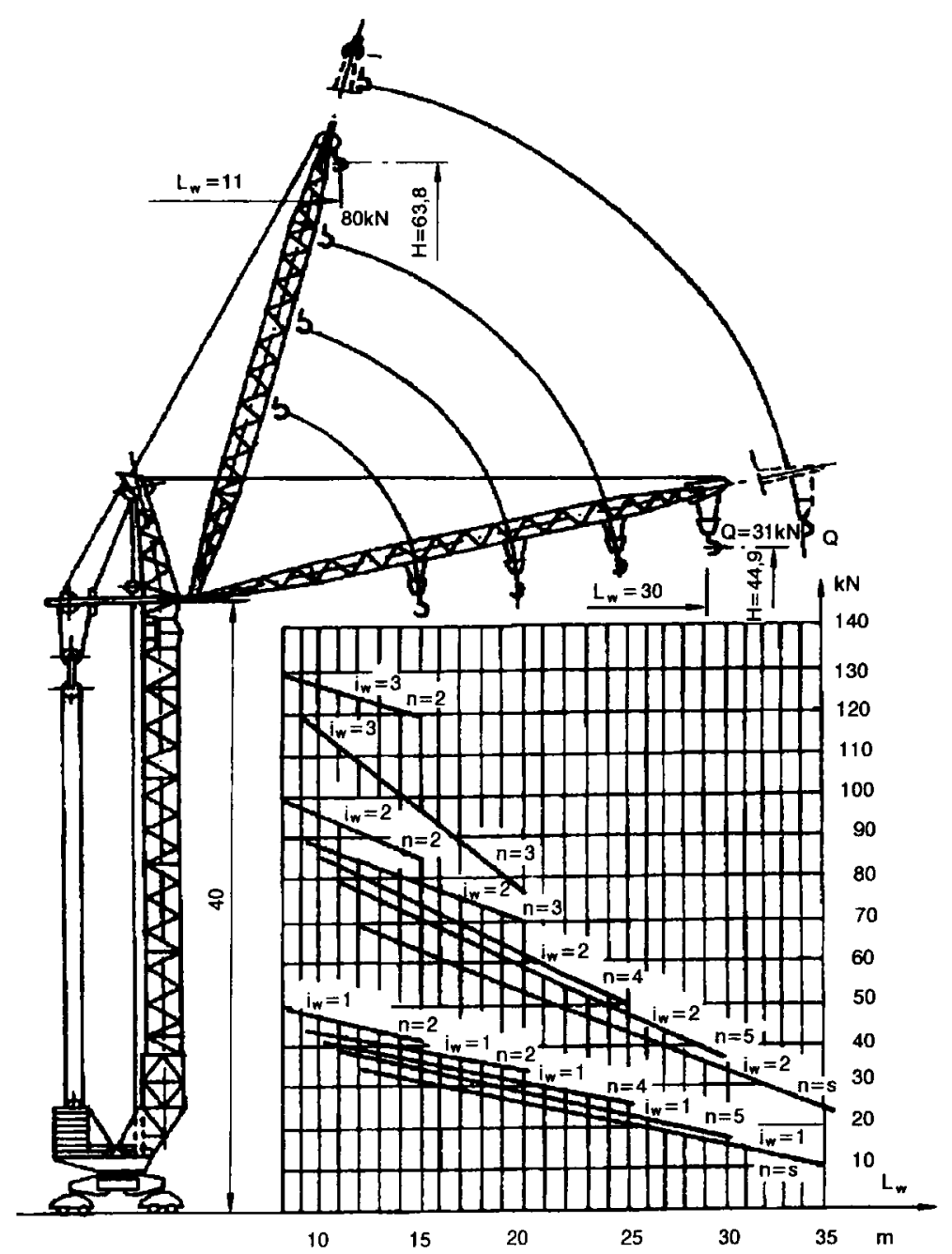

Fig 2. Information on the crane ŻB-125/180 as presented in the catalogue [8]

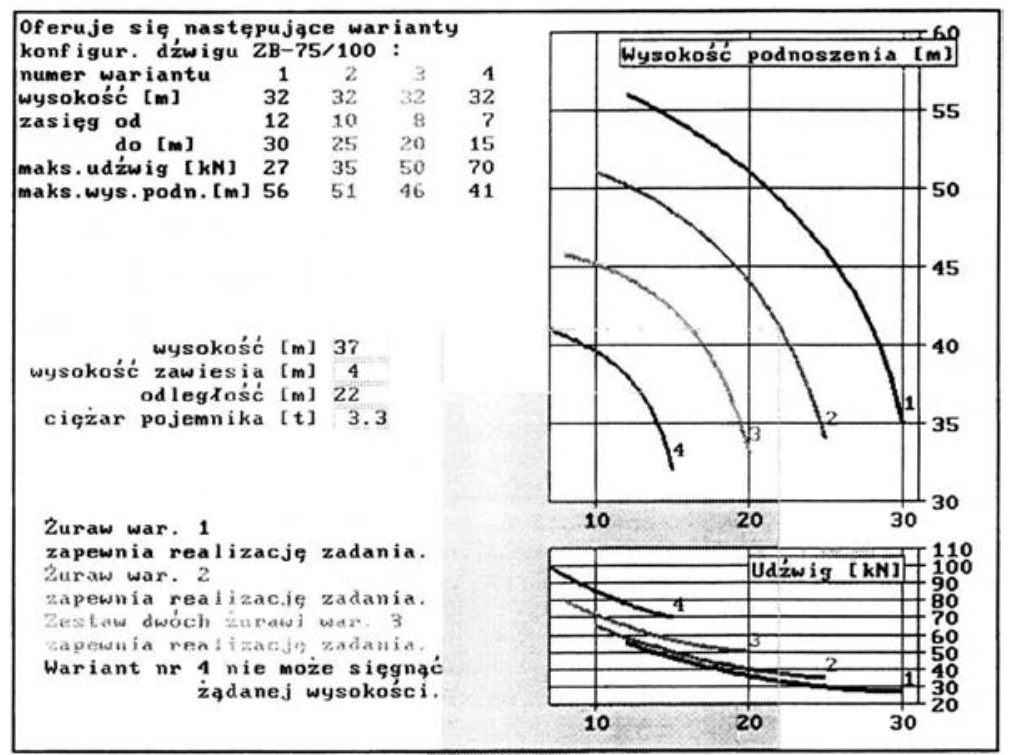

Fig 3. Presented graphs are produced by equations describing the changes in the lifting height and the loading capacity (4 upper curves and 4 lower lines, respectively) of four combinations of the ŻB-75/100 segments. The user enters four parameters (height of the silos, operation distance from the axis, the weight of the container; here they are equal to $37 \mathrm{~m}, 4 \mathrm{~m}, 22 \mathrm{~m}$ and 3.3 tons, respectively) and the program says which combination satisfies the requirements determined by these 4 parameters. In the case the construction can be realised by the cranes No 1 or No 2, by two cranes No 3 (the maximal range of the jib operation is 20 meters), and cannot be by the crane No 4 (it does not reach the height of 41 meters) 
The equations describing the behaviour of the loading capacity as the function of the operating distance to the tower axis of the crane can be included in the program in various ways. If we admit various shapes, the most natural way is their memorisation in the form of function. In case of the crane ŻB-75/100 disposed in four configurations this function writes down in Pascal as follows (the comments say which values were used to generate the interpolary parabola):

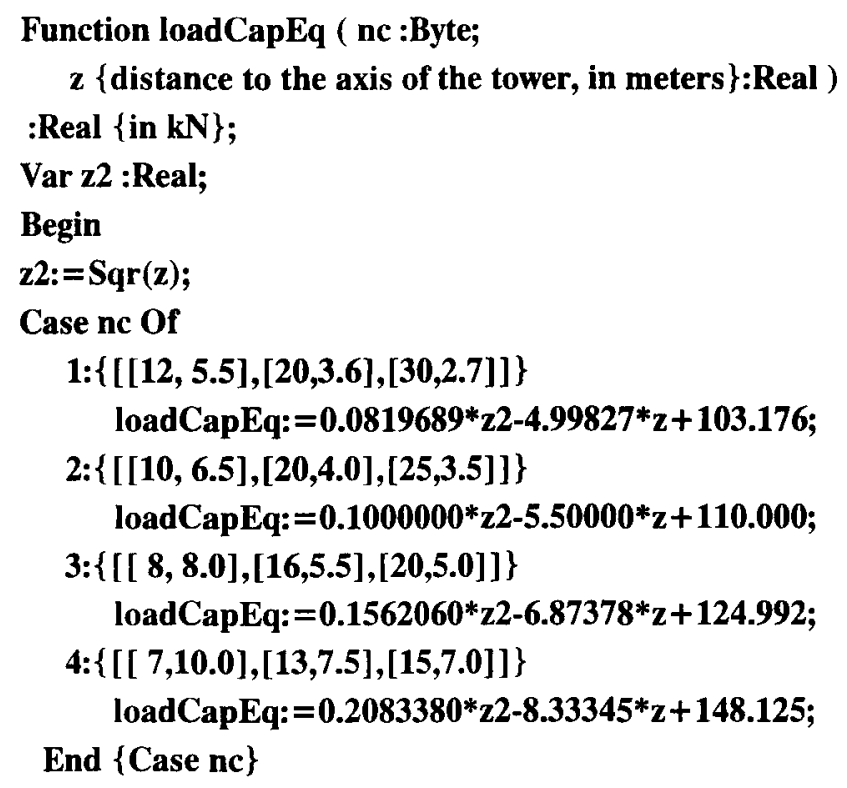

If we only admit the hyperbolic behaviour of the form $z \rightarrow a / z+b$ (as it takes place for the crane Waryński-Wolf), we can use the tables (for the coefficients $a$ and $b$ ) as follows

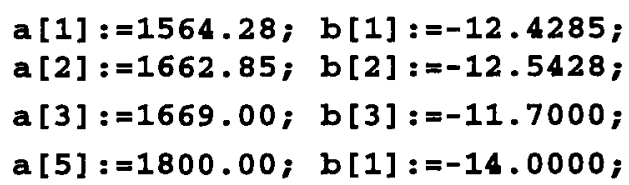

or we can read these coefficients from a disk file where they are arranged as follows:
nc a[nc] b[nc]
1 1564.28 - 12.4285
$\begin{array}{llll}2 & 1662.85 & -12.5428\end{array}$
$3 \quad 1669.00-11.7000$
$41800.00-14.0000$

Numbers given above relates to 4 configurations of the crane Waryński-Wolf (see [7] for details).

\section{Describing the movement of the crane arm}

Unfortunately, the simple solution discussed above can not be applied in all situations. For example, it does not permit to describe the curves drawn by the arms of the crane ŻB-75/100 (see Fig 1). Detailed analysis of these curves reveals that they are not arcs of circles. This is the consequence of many singular motions of the crane mechanisms (especially single or doubled pulley blocks and multiblocks controlling the movement of the jib) composing a complex behaviour of the whole. A satisfactory description was attained in the class of rational functions having form $\mathrm{z} \rightarrow \mathrm{a} /(\mathrm{z}-$ $z 0)+a \cdot z^{2}+b \cdot z+c$ (as in the previous section, $z$ stays for the distance from the tower crane axis). Here it is the Pascal function furnishing the expressions (produced on the base of data listed in the comment parentheses \{\} ): 


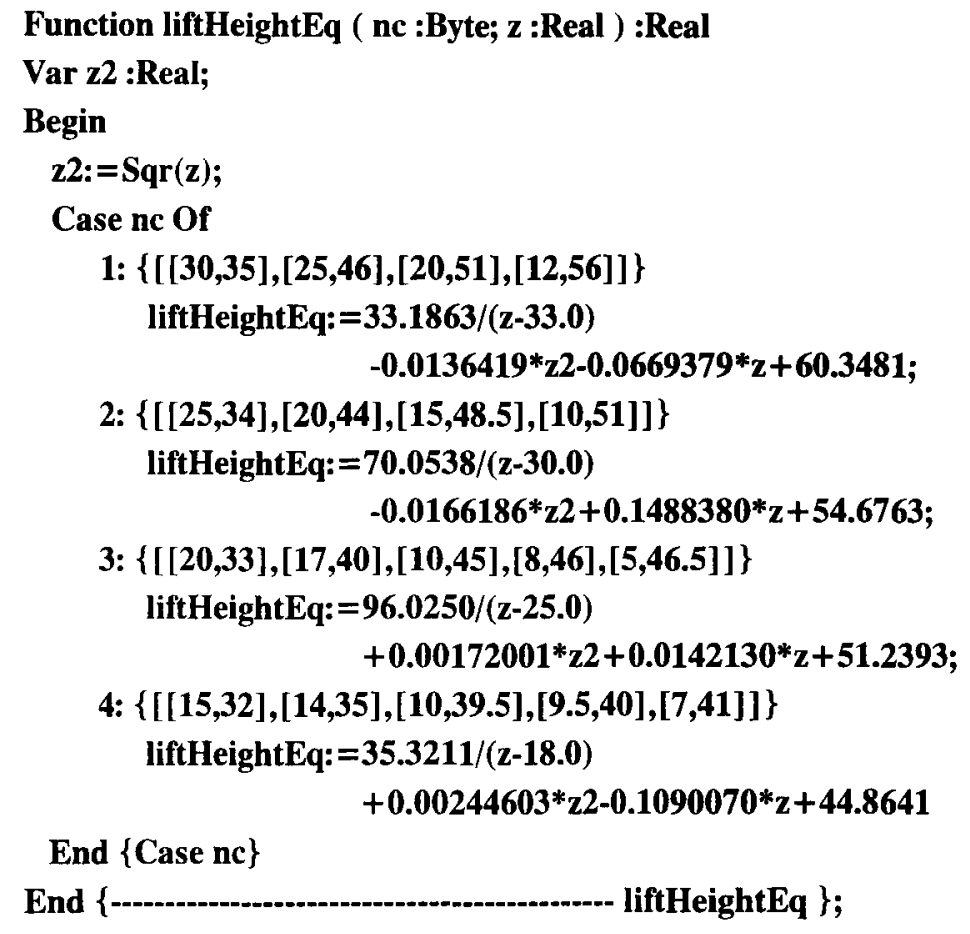

The above code is a part of this unit of an expert system where the micro-rules (technological rules) are written down within the if-then clause:

IF $B \cdot R \leq C 1$ ( $\mathbf{C l}$ is visualised by a fragment of an hyperbola, a parabola, a cosine line, etc)

AND $\mathrm{H} \leq \mathrm{C} 2$ ( $\mathrm{C2}$ is visualised by a fragment of a circle, a rational function, etc)

THEN show the list of appropriate cranes cooperating with selected bucket in the projected object (silo),

where:

B - weight of the bucket filled with concrete,

$\mathbf{R}$ - operation range of the crane,

C1 - value of the working momentum which has been read from the behaviour line,

$\mathbf{H}$ - height of the buliding (silo),

C2 - value taken from the curve of the lifting capacity.

\section{Pro and contra of some approach to data storing}

Taking into account the difficulties signalised above, it is obvious that nobody expects that a common user of any expert system will look for analytical expressions describing the behaviour of such lines as that limiting the load capacity of the crane or sketched by the hook of the crane arm. That's why our computer program has to include appropriate codes or has to be able to interpretate the discrete data.
Programmers opting for the second solution restricts himself, in practice, to the use of spline interpolation (eg [8]). Naturally, this approximation is very sensitive to values of given points, so it is easy to erroneously accept or reject a considered crane. Moreover, the graphs of spline functions very often are not monotony (small oscillations appear), so they lose the behaviour which is natural within the discussed phenomena. In spite of these faults this approach is universally applied and makes no damages if a high precision is not expected (results produced by the computer are applied after their modification by a safety coefficient). It also do not astonish if graphs are not displayed.

The first solution needs no effort from the user, (s)he buys the system equipped with a unit contained the definitions of functions describing considered dependencies. Naturally, this set must be limited to the most frequently used combinations of the most popular cranes. This results with no possibility a new (combination of the) crane to be enclosed in the analysis made by the system. The only exception is when the expert system is open. This feature can be realised in two ways. One way is the ability to recognize the strings of characters. In practice it means that the system includes an interpreter of the formulas (and it is really difficult task to elaborate such an unit dealing within relatively wide area). Another way is when the program can be enriched with codes of new 
functions or allows to changes its fragments. In Pascal (and other languages qualified as NOLs, [9]) it is possible if a source code can be manipulated. This require any skills, so this way can be advised to well trained programmers only. In spite of it we talk here about it because there is the way in which the best approximation works (and we equip our expert system with the function such as loadCapEq and liftHeightEq).

\section{Applying DERIVE to get analytical expressions}

There are many ways for producing analytic expressions describing the (approximate) relations between independent and dependent variables. The most popular are the collocation procedures (here there are included that resulting with Lagrange and Newton inter-polatory polynomials, and Herriot-Reinsch algorithm for the cubic spline approximation) and the least square approximation (LSA). The last mentioned is smoothing the data, so it is, in general, most suitable to be applied for finding the formulas covering the behaviour of the dependencies of load capacity and maximum height within the operating distance of the crane. In many cases one of the most burdensome problems in the LSA is to indicate a class (ie the form) of functions where the best fit is to be found. As it has been shown above, we have got this problem because there is no simple rule to say which form of expression serves in the best way. The acceptation of the approximation form is not reduced only to the value of the approximation error, so it is worthy to have a tool which rapidly can both determine the coefficients of approximating expression and plot the obtained curve (what permits to estimate its goodness in terms other than the error mentioned above). We can propose here such a tool, it is DERIVE.

DERIVE is the computer algebra system produced by the Hawaiian enterprise Soft Warehouse, Inc. In spite of its moderate hardware requirements it provides functions dealing with a lot of complicated problems [10]. Version 3.10 of this program manages the screen as it is shown in Fig 3 and offers, among others, the function FIT and the command Plot. The function FIT produces within the anticipated class (k) of functions of indicated variable ( $x$ ) the LSA to the data collected in a matrix (m). The command Plot produces the image of the expression which is currently highlighted. In particular, if appropriate options (managing the graphical window) are on, this command visualises a two-column matrix as the set of points (the abscissa are elements of the first column, the ordinates are that of the second column), and the algebraic expression including at most one variable as the graph (of the function depending on this variable). In Fig 4 there are shown these points and curves which are parabolas. It means we dealt within the class of function having the form:

$$
\mathbf{k}(\mathbf{x})=\mathbf{a}+\mathbf{b} \cdot \mathbf{x}+\mathbf{c} \cdot \mathbf{x}^{2}
$$

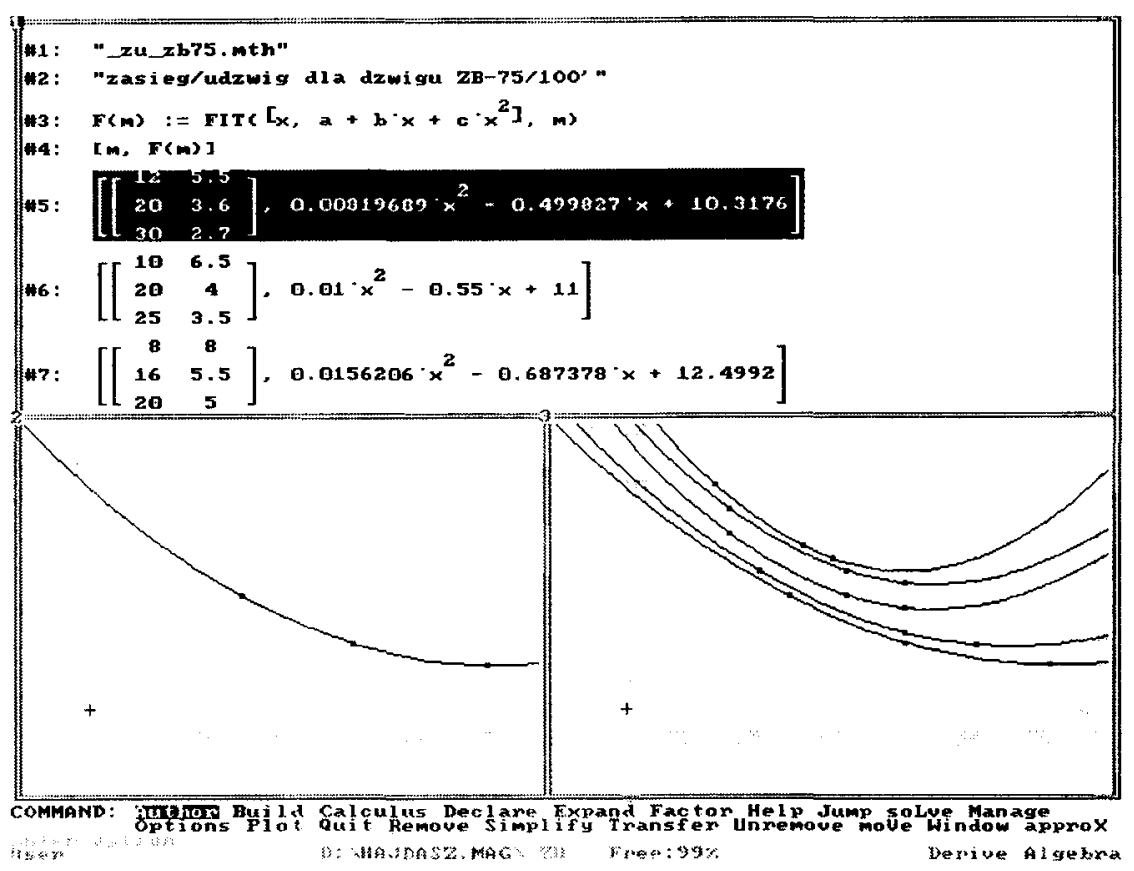

Fig 4. A sample screen managed by the program DERIVE 3.10 
This right side of this expression forms one of the arguments of the standard function FIT.

We can see it in Fig 4. The upper part is occupied by the algebra screen, here we see successively: two auxiliary texts (name of the file and the subject to be realised, ie the discovering of the relation between the range and the capacity of the crane ZB-75/100), the definitions of the function $\mathbf{F}(\mathbf{m})$ and the vector $[\mathbf{m}, \mathbf{F}(\mathbf{m})]$, and the expressions produced for some matrices $\mathbf{m}$ by the command approX (it is the last command offered in the command line). The left graphical window contains the image of the expression No 5 (it is highlighted in the window No 1). This image is composed of three points (their co-ordinates constitute the matrix $\mathbf{m}$ ) and the arc of the parabola passing through these points, its equation is

$$
y=0.00819689 x^{2}-0.499827 x+10.3176
$$

In the window No 3 there are five parabolic arcs generated by the expression No 4 realised for the data supplied by the documentation of the crane ŻB-75/100 (these are the same curves as in Fig 1).

\section{References}

1. Expert Systems in Engineering (ed. by D.T. Pham). Artificial Intelligence in Industry series, IFS Publications and Springer-Verlag, Berlin-New York, 1988.

2. M. Bazewicz. Metody $i$ techniki reprezentacji wiedzy $w$ projektowaniu systemów, Wyd. Politechniki Wrocławskiej, 1994.

3. C. Gray, J. Little. A systematic approach to the selection of an appropriate crane for a construction site // Construction Management and Economics, 1985, 3, p. 121144.

4. M. Hajdasz, A. Marlewski. Założenia systemu ekspertowego do projektowania wykonawstwa obiektów realizowanych $w$ technologiach monolitycznych // XLIII konf. nauk. "Problemy naukowo-badawcze budownictwa" - Krynica'97 (Poznań), Vol VII, p. 19-25.

5. T. Sokół. An algorithm for optimal selection of building cranes at building sites // Metody Komputerowe w Inżynierii Lądowej (Warszawa), Vol 2, No 4, 1992, p. 5765 .

6. A. Minasowicz, T. Szczepański. Computer-aided cranes system for building industry CRAB) // Metody Komputerowe w Inżynierii Lądowej (Warszawa), Tom 2, $\mathrm{Nr} 4,1992$, p. 39-55.

7. Technologia robót budowlanych, ed. W. Lenkiewicz, PWN, 1985.

8. R.L. Burnes, J.D. Faires. Numerical analysis, PWS-Kent Publishing Company. Boston, 1985.
9. A. Marlewski. When a Fortraner or Pascaler becomes Deriver or Mapler // Conference on Teaching Mathematics with Derive and the TI-92, Schlo $\beta$ Birlinghoven, July 2-6,1996, Westfällische Willhelms Universität Mü nster 1997, p. 338-346.

10. A. Marlewski. DERIVE 3.0, Nakom, Poznań 1995.

Itteikta 19971125

\section{IPRASTINĖS INFORMACIJOS APIE KRANUS PRTTAI- KYMAS EKSPERTU SISTEMOS REIKALAVIMAMS}

\section{Hajdasz, A. Marlewski}

S a n tra u k a

Svarbus ekspertų sistemos uždavinys, susijęs su monolitinès statybos projektavimu, yra tinkamai pasirinkti kranus. Pagal apibrèžimą bet kuri ekspertụ sistema turi būti patikimas vadovo pagalbininkas, todèl reikia atsižvelgti $\mathfrak{i}$ tokius dalykus, kaip diagramų, nomogramų, lentelių ir normų naudojimą. Kompiuterinè technika kelia tam tikrus reikalavimus, pavyzdžiui, duomenys turi būti visapusiški, vienodai pateikti ir tinkamai transformuoti, kad galètų būti efektyviai naudojami. Šiame straipsnyje aptariama keletas problemų, susijusių su duomenų gavimu ir jụ pritaikymu turimos sistemos specifikai. Svarstoma, kaip pateikti kranu keliamosios galios skirtumus ir didžiausią aukští, kurị gali pasiekti krano kubilai, keliantys betoną. Analizuojama keletas būdų, kaip saugoti tokią informaciją (lenteles, funkcijas ir kt.) ir pateikiami keli pavyzdžiai Paskalio kalba. Parodoma, kaip taikyti programą DERIVE, kai norima gauti kai kurių algebros funkcijų aprašymą. Be to, pažymima, kad detalesnis šios problemos nagrinejjimas gali atskleisti netikètų dalykų (pvz., krano strèlè apskritimo lanku nejuda).

Magdalena HAJDASZ. MSc (civil engineering), Assistant. Institute of Structural Engineering. Poznań University of Technology, ul. Piotrowo 5, 60-245 Poznań, Poland.

A graduate of Poznań University of Technology (1980). Author of 11 papers. Research interests: technology and organisation of monolithic constructions, expert systems.

Adam MARLEWSKI. PhD (mathematics), Assistant Professor. Institute of Mathematics. Poznań University of Technology, ul. Piotrowo 3a, 60-245 Poznań, Poland; e-mail: amarlew@math.put.poznan.pl.

A graduate of Adam Mickiewicz University in Poznan (1968). Doctor's degree in 1981 at Poznań University of Technology. In 1992-94 visiting professor in Covilha (Portugal). Research interests: approximation theory, numerical methods, computer algebra systems. Author of 40 articles (including 20 written in co-operation with engineers), 2 manuals for students (Algebra and Graph Theory, Practical Classes in Numerical Methods) and 3 books (DERIVE 2, PC Tools 7.1, DERIVE 3.0). 